\title{
FACTORS ASSOCIATED WITH INFANT MORTALITY IN THE METROPOLITAN REGION OF CARIRI, CEARÁ, BRAZIL
}

\author{
Andréa Couto Feitosa ${ }^{1,2}$, Edige Felipe de Sousa Santos ${ }^{1,2}$, José Lucas Souza Ramos ${ }^{1}$, \\ Italla Maria Pinheiro Bezerra ${ }^{1}$, Viviane Gabriela Nascimento ${ }^{1}$, Cicero Cruz Macedo ${ }^{1,3}$, \\ Hugo Macedo Jr' ${ }^{1}$, Luiz Carlos de Abreu ${ }^{1}$
}

DOI: http://dx.doi.org/10.7322/jhgd.103019

\begin{abstract}
:
Introduction: The identification of factors related to children's deaths is very important in planning public health actions for restructure and improve the mother and child assistance, aimed in reducing child mortality. Objective: Analyze the factors associated with infant mortality in the metropolitan area of Cariri, Ceará, Brazil. Methods: This is a cross-sectional study. All deaths occurring in children under one year old of the metropolitan region of Cariri, Ceará, Brazil, contained in the mortality information system and in live births's information system, from January 2009 to December 2013. Newborn variables (sex, race/color, weight, age); maternal variables (maternal age and education and type of gestation); assistance variables (labor type) were extracted from the SUS (Sistema Único de Saúde/Unified Health System) Informatics Department and presented in chart and tables in absolute and percentage frequency form. Results: In the five-year period, 816 infant deaths in 48321 births were registered associated to the following factors: $453(55.5 \%)$ male, $471(57.7 \%)$ drab and $514(63 \%)$ low weight in birth, $458(56.1 \%)$ with 20 to 34 years of age, $353(43.2 \%) 8$ years or more of schooling, $657(80.5 \%)$ only pregnancy and $414(50.7 \%)$ vaginal birth. Conclusion: Infant mortality variables in the metropolitan region of Cariri, Ceará, Brazil were associated mostly with deaths occurring in drab boys with birth weight below the normal, whose mothers were young, with good education and who had just one gestation, born of vaginal birth.
\end{abstract}

Key words: risk factors, low birth weight Infant, Maternal Age, perinatal assistance.

\section{INTRODUCTION}

Infant mortality is considered the primary indicator for analyzing health's general state of the population, especially with regard to the quality of the prenatal mother and child assistance, childbirth and the postpartum period.

In recent years, despite the decline in Infant Mortality Coefficient (IMC), the absolute number of deaths in children under one year is still representing a serious public health problem.

In the year 2000, the United Nations (UN), analyzing the biggest global problems, established eight Millennium Development Goals (MDGs). The fourth goal was the infant mortality reduction, which aims to reduce $2 / 3$ of the overall rate of infant mortality between 1990 and $2015^{1}$.

To achieve the fourth MDG, a fast enlargement of child health interventions in different countries is needed. To support this process, in addition to increasing the frequent monitoring ${ }^{2}$, it is important to promote the correct registration of the death declaration, as well as improve the root cause, strengthening national health information systems, that will allow future estimates of infant mortality ${ }^{3}$.

Public health presents two main challenges to achieve the reduction of children's deaths. One is the big disparity in infant mortality risk between developed and developing countries. The other is the emerging role of neonatal mortality as a IMC major component. In 2012, most infant mortality rate of children under five years (IMRCU5) occurred in the low-income countries, as example subSaharan Africa and South Asia, where the IMRCU5 rates were 98 and 58 per 1000 live births, respectively 4 .

In Brazil, the millennium goal aimed to decrease from 58 deaths for every 1,000 children born alive in 1990 to 19 per 1,000 born alives in 2015. However, in the end of 2011, the reduction in mortality rate had already been reached ${ }^{5}$. The expansion in the health area, such as prenatal care and during childbirth also improved, influencing the

1 Laboratório de Delineamento de Estudos e Escrita Científica. Faculdade de Medicina do ABC, Santo André, SP..

2 Docente da Faculdade Leão Sampaio. Juazeiro do Norte, CE, Brasil.

3 Docente do Departamento de Pediatria da Universidade Federal do Cariri- UFCA. Barbalha, CE, Brasil.

Corresponding author: Andréa Couto Feitosa. E-mail: andreafeitosa@leaosampaio.edu.br

Suggested citation: Feitosa AC, Santos JLS, Bezerra IMP, Nascimento VG, Macedo CC, et al. Factors associated with infant mortality in the metropolitan region of Cariri, Ceará, Brazil. Journal of Human Growth and Development. 25(2): 224-229. DOI: http://dx.doi.org/ $10.7322 /$ jhgd.103019

Manuscript submitted: nov 06 2014. Accepted for publication: aug 252015. 
maternal characteristics in the reduction of children death ${ }^{6}$.

In the state of Ceará, Brazil, the epidemiological situation of infant mortality accompanies the national context of gradual reduction. The IMC evolution and its components, between 1997 and 2013, presented 57\% reduction, from 31.6 in 1997 to 13.6 deaths per 1,000 live births in the year $2013^{5}$.

In the metropolitan region of Cariri, Ceará, Brazil, in the last five years, infant mortality has undergone a gradual increase, except in 2012, passing from $15.2 / 1,000$ live births in 2009 , to 16.8 / 1,000 live births in 2013 . However, the associated factors for this variation have not been described yet.

In this way, the infant mortality monitoring and the study of the risk factors involved in its causal chain are fundamental to understand child population living conditions and to define public policies actions, appropriate to each reality, by promoting strategies that allow the healthcare network control and organization?. Therefore, reduce the infant mortality rate has been one of the main priorities of social and health policies of the Brazilian Government for several decades.

Thus, the objective of this study is to analyze the factors associated with infant mortality in the metropolitan area of Cariri, Ceará, Brazil.

\section{METHODS}

This is a descriptive study, with a quantitative approach. For the territorial clipping, it was selected the Metropolitan Area of Cariri (MAC), located in the South of Ceará, northeastern Brazil, comprising nine municipalities, four of them from the Crato's 20th Regional Health Coordination (RHC), which are: Crato, Farias Brito, Santana do Cariri and Nova Olinda, and five of Juazeiro do Norte's 21st RHS:
Barbalha, Missão Velha, Caririaçu, Jardim and Juazeiro do Norte. This area had a population of 564,478 inhabitants at the time of census $2010^{8}$.

All deaths happened in children under one year old of the municipalities of the metropolitan region of Cariri, Ceará, Brazil, registered in the mortality information system and live births information system from January 2009 to December 2013. A form was used for extraction of the following variables: from the newborn (sex, race/color and weight at birth), from the mom (maternalage, education and type of gestation) and social assistance (labor type) being taken from the Informatics Department of the Unified Health System (DATASUS) through the address www.datasus.gov.br, which still features incomplete coverage, being only $90 \%$ to total deaths and $71 \%$ for deaths of children under one year in the Mortality Information System (MIS) in the country, being held by the Health Ministry ${ }^{9}$.

These data were collected related to year of death, the metropolitan region of Cariri and small cities around this area. Descriptive statistics was used and presented in chart and tables in the form of absolute and percentage frequency.

The study was approved by Ethics Committee in Research (ECR) of the Faculty of Medicine of ABC, on March 8, 2013, according the protocol 214,586.

\section{RESULTS}

In the five-year period, 816 deaths in 48321 children born alive were registered. When the newborn factors were analyzed, it was found that $55.5 \%$ of infant deaths were male, followed by $40 \%$ female. In relation to the race/color, $57.7 \%$ of infant deaths occurred in drab children. For this variable, $12 \%$ of information was classified as ignored. As for birth weight, $63 \%$ were underweight, with $13 \%$ dropped data (Table 1).

Table 1: The proportion of deaths in children under 1 year of age, according to the factors related to newborns in the municipalities of the metropolitan regions of Cariri, Ceará, Brazil, 2009-2013

\begin{tabular}{|c|c|c|c|c|c|c|c|c|c|c|c|c|}
\hline \multirow{3}{*}{ Variables } & \multicolumn{12}{|c|}{ THE METROPOLITAM REGION OF BRAZIL } \\
\hline & \multicolumn{2}{|c|}{2009} & \multicolumn{2}{|c|}{2010} & \multicolumn{2}{|c|}{2011} & \multicolumn{2}{|c|}{2012} & \multicolumn{2}{|c|}{2013} & \multicolumn{2}{|c|}{ Total } \\
\hline & $\mathbf{N}$ & $\%$ & $\mathbf{N}$ & $\%$ & $\mathbf{N}$ & $\%$ & $\mathbf{N}$ & $\%$ & $\mathbf{N}$ & $\%$ & $\mathbf{N}$ & $\%$ \\
\hline \multicolumn{13}{|l|}{ Sex } \\
\hline Male & 94 & 61,8 & 94 & 55,9 & 93 & 50,8 & 74 & 51,0 & 98 & 58,3 & 453 & 55,5 \\
\hline Female & 49 & 32,2 & 68 & 40,5 & 82 & 44,8 & 64 & 44,1 & 63 & 37,5 & 326 & 40 \\
\hline Ignored & 09 & 6,0 & 06 & 3,6 & 08 & 4,4 & 07 & 4,9 & 07 & 4,2 & 07 & 4,5 \\
\hline Total & 152 & 100 & 168 & 100 & 183 & 100 & 145 & 100 & 168 & 100 & 816 & 100 \\
\hline \multicolumn{13}{|l|}{ Race/Color } \\
\hline Whith & 33 & 21,7 & 55 & 32,7 & 62 & 35,0 & 40 & 27,6 & 46 & 27,4 & 238 & 29,2 \\
\hline Black & 02 & 1,3 & 0,2 & 1,2 & 0,2 & 1,1 & - & - & 01 & 0,6 & 07 & 0,9 \\
\hline Yellow & - & - & - & - & 01 & 0,7 & - & - & - & - & 01 & 0,1 \\
\hline Parda & 104 & 68,4 & 101 & 60,1 & 97 & 53,0 & 79 & 54,5 & 90 & 53,6 & 471 & 57,7 \\
\hline Indgenous & - & - & - & - & - & - & 01 & 0,7 & - & - & 01 & 0,1 \\
\hline Ignored & 13 & 8,6 & 10 & 6,0 & 19 & 10,3 & 25 & 17,2 & 31 & 18,4 & 98 & 12,0 \\
\hline Total & 152 & 100 & 158 & 100 & 183 & 100 & 145 & 100 & 168 & 100 & 816 & 100 \\
\hline \multicolumn{13}{|c|}{ Total birth wight } \\
\hline Up to 2,499 & 93 & 61,2 & 101 & 60,1 & 121 & 66,1 & 91 & 62,8 & 108 & 64,3 & 514 & 63,0 \\
\hline$\geq 2,500$ & 33 & 21,7 & 45 & 26,8 & 43 & 23,5 & 36 & 24,8 & 39 & 23,2 & 196 & 24,0 \\
\hline Ignored & 26 & 17,1 & 22 & 13,1 & 19 & 10,4 & 18 & 12,4 & 21 & 12,5 & 106 & 13,0 \\
\hline Total & 152 & 100 & 168 & 100 & 183 & 100 & 145 & 100 & 168 & 100 & 816 & 100 \\
\hline
\end{tabular}

Source: MIS database via DATASUS, 2014. 
According to the maternal factors, it was found that $56.1 \%$ of children under 1 year of age deaths were from mothers aged 20 to 34 years of age, with $10.9 \%$ of missing data. As maternal education, $43.2 \%$ had 8 or more years of study, with $16.7 \%$ ignored. Related to the type of gestation, $80.5 \%$ had been in the first gestation, and $8.4 \%$ ignored the question (Table 2 ).

Table 2: The proportion of deaths in children under 1 year, according to maternal factors in the municipalities of the metropolitan region of Brazil, 2009-2013. ${ }^{3}$

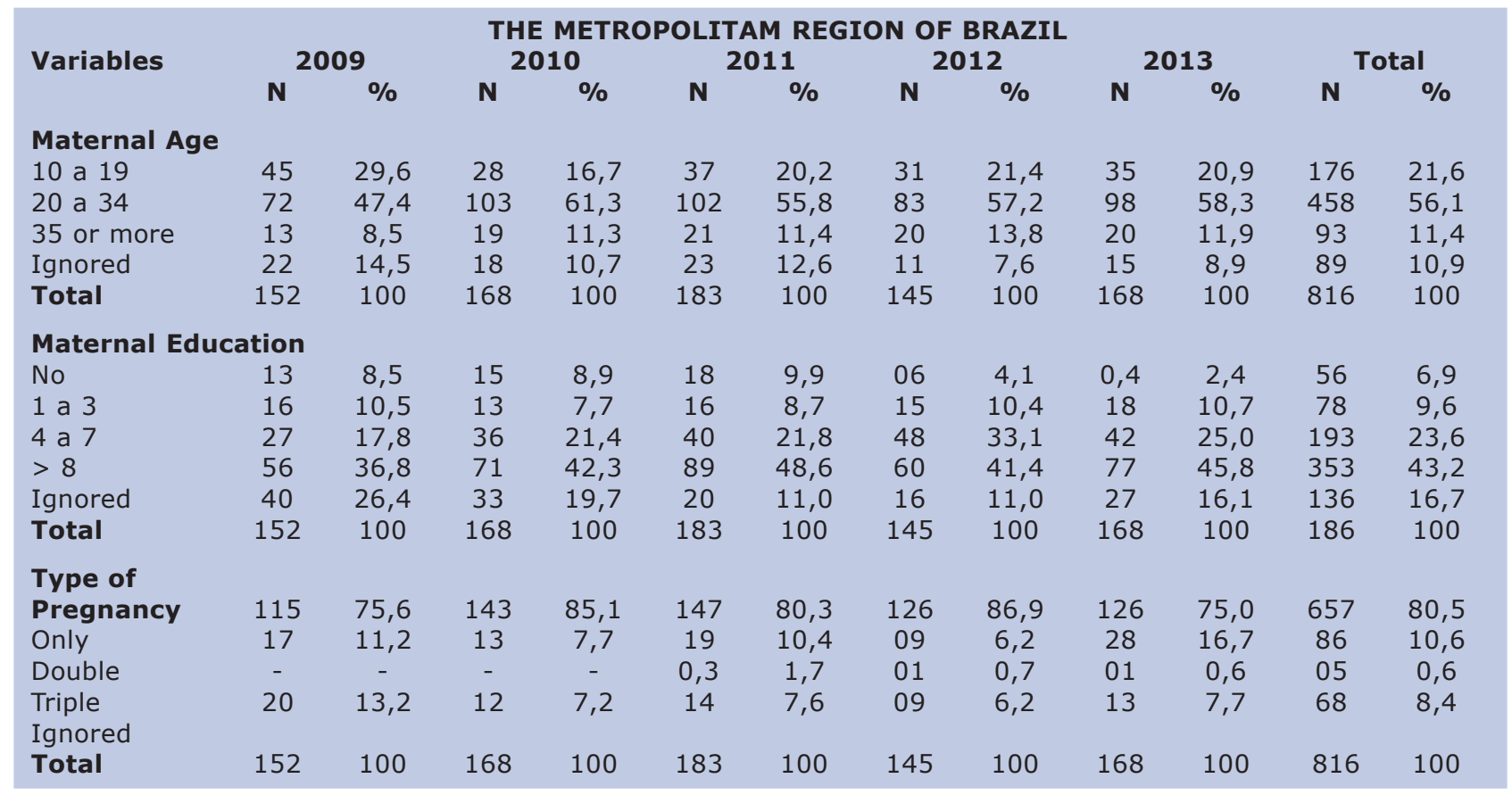

Source: MIS database via DATASUS, 2014.

According to welfare factors associated with infant mortality, $50.7 \%$ of the deaths occurred in children born by vaginal labor, followed by $39.3 \%$ by cesarean section and $10 \%$ of the records were classified as unknown (Table 3 ).

Table 3: Proportion of deaths in children under1 year of age, according to the municipal social assistance factors in the metropolitan region of Cariri, Ceará, Brazil, 2009-2013

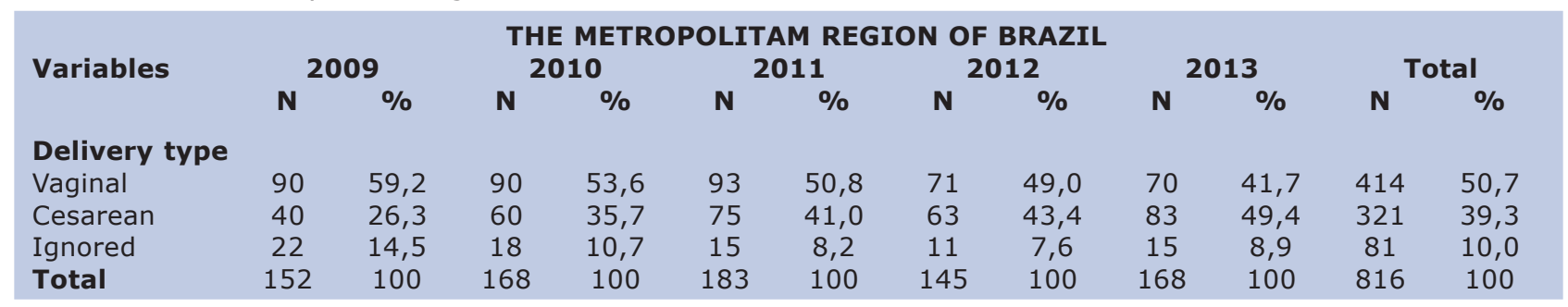

Source: MIS database via DATASUS, 2014.

\section{DISCUSSION}

Infant mortality related factors in the metropolitan region of Cariri showed association with deaths occurring in drab boys, whose birth weight was below normal, whose mothers had age between 20 to 34 years, with 8 or more years of study and who have had only one gestation and vaginal birth.

In Brazil, socioeconomic and cultural differences led to a high degree of heterogeneity among Brazilian regions, besides the access to health services iniquities, resulting in the survival of newborns. Thus, it becomes necessary to research local risk factors ${ }^{10}$.
Out of the 816 deaths, the majority (55.5\%) occurred in males. According to the association between risk of death in children under one year and newborn's sex, it was found that boys will present 1.6 times the risk for mortality during neonatal period, while girls present a faster lung maturation as a protection and, consequently, lower respiratory complications ${ }^{11}$.

The majority of live births that have evolved to death in the first week of life were mostly male, premature and with low birth weight ${ }^{12}$. In a study realized in Pelotas, Rio Grande do Sul, Brazil, also identified increased risk of death in boys ${ }^{13}$.

It was observed a greater proportion of deaths in drab children (57.7\%), diverging from 
results found in other studies ${ }^{14}$, where there was a higher incidence of deaths in drab children in the period from 2006 to 2010, by which time there were larger numbers of infant deaths in the city of Porto Velho, Rondônia, Brazil. Race/color information in Brazil represent doubtful question, since identifying race/color in children under a year old still represents a challenge for professionals who register or notify the event.

Low birth weight is considered one of the most important public health problems in the world, contributing substantially to the infant mortality. The Low Birth Weight (LBW) is due to prematurity and/or intrauterine growth retardation and is associated with about 4 million annual neonatal deaths that occur in the world, most of them in developing countries ${ }^{11.15}$.

The results of this study indicate $63 \%$ of deaths with weight up to $2,499 \mathrm{~g}$, in other words, the vast majority are classified as a low birth weight child. The risk of infant mortality in children with low birth weight corresponds to 200 times the risk of mortality in children born with proper weight ${ }^{16}$.

Deaths associated with low birth weight can be minimized with proper prenatal care, requiring, for this, affordable, appropriate and with good quality services. In addition, in Brazil, the Integrated Management of Childhood IIness (IMCI) strategy, already used, also contributes to the reduction of neonatal mortality.

The beginning and fulfillment of prenatal care are affected by maternal age. Only a third of mothers under 15 years of age, and about half of people aged 15-19 tend to receive prenatal care in the first quarter, indicating that young mothers were less likely to seek and receive regular prenatal care. On the contrary, more than $70 \%$ of mothers aged 25 years or older began prenatal care early ${ }^{17}$.

About the maternal variables, mother's age is one of the factors associated with infant mortality. This study identified that the majority (56.1\%) of the mothers had age between 20 to 34 years old, showing similar results ${ }^{14}$, that show a predominance of mothers with the same age group, whose percentages ranged from $26 \%$ in 2006 to $29 \%$ in 2010.

Studies ensure that precocity or postponement of motherhood was positively associated to children's deaths ${ }^{14}$. On other hand, in other research ${ }^{16}$, fetal and neonatal mortality were associated only to maternal age factor, finding no significant results with teenage mothers.

Maternal schooling can influence access and adherence to prenatal care, with consequent impact on frequency of consultations and pregnancy monitoring, reflecting on the chance of pregnancy complication. Maternal Education has shown to be an important factor for infant mortality reduction, independent of other factors. It is believed that the high education of mothers improves in child survival through knowledge about the effective ways to prevent, recognize and treat childhood diseases ${ }^{18}$.

In this study, children's deaths were associated with the high level of maternal education, in which $43.2 \%$ of mothers presented less than eight years of schooling, different from the research ${ }^{19}$ that found that the increased maternal education contributed to the decline of infant mortality rates and its neonatal and post neonatal components.

The accuracy and completeness of the records may influence the secondary data analysis. Even with the evident improvement in the coverage and quality of the records of Mortality Information System (MIS), the crashes still persist in the Death Declaration (DD). In the study, the maternal schooling condition was the variable that showed the highest ignored data record (16.7\%).

Most of the deaths (80.5\%) were from only one pregnancy, converging with other data ${ }^{20}$ that indicate that $77.6 \%$ of infant deaths arise out of only one pregnancy. Diverging from this result, another study ${ }^{21}$ verified that deaths are associated to multiple pregnancy, as they may increase the chance of premature birth and low birth weight, both infant death determinants.

The study region presented cesarean delivery proportion above $(39.3 \%)$ the acceptable by the World Health Organization, which advocates that such delivery shall not exceed $15 \%$ of the total ${ }^{22}$. The increase in cesarean births number may be related to the operating processes scheduled and the occurrence of before childbirth ${ }^{22}$. Another study identified that the cesarean labor proved to be a protective factor for reducing infant mortality?.

Even with that, the caesarean labor was not the main delivery type associated to the infant's death, while vaginal birth corresponded to $50.7 \%$ of deaths. This is the incentive policy of the Brazilian unified health system in reducing the surgical births, in order to minimize health costs and optimize the recovery of mothers. Is important to remark that Brazil is one of the countries with the highest rates of Cesarean section in the world and policies to reverse this situation are always welcome ${ }^{23}$.

The research demonstrated the monitoring needed in relation to the provision of appropriate care to the newborns with higher mortality risk, as well as the managers responsibility of ensure a quality prenatal care, and particularly for women with the most unfavorable sociodemographic characteristics. In addition, a more in-depth look to municipalities is necessary for delivery and newborn assistance, and it is important to evaluate the structure of the perinatal network and the quality of the received attention to reduce the mortality indicator

As this is a cross-sectional study, one of its limitations is that it cannot be inferred that the factors identified are defined as risk factors, since it would require a follow-up or cohort study. However, this study is valid for generating causality hypotheses, as well as to identify the main factors associated with infant deaths. Like any secondary data study, the quality of the information can be impaired due to the elevation of the dropped data.

Thus, the official records allow the identification of infant mortality-related factors in the metropolitan region of Cariri, Ceará, Brazil, associated mostly with deaths occurring in drab boys whose birth weight was below normal, whose mothers were young, with good education and who had only one gestation, born of vaginal birth. 
This study has shown that the influence of factors related to maternal and newborn assistance have in relation to children's deaths demonstrates the variable low birth weight presents a greater vulnerability compared with other, requiring, in this way, health services to invest in improving the quality of prenatal and childbirth care, in addition to the frequent monitoring of these newborns of low birth weight.

The infant mortality coefficient represents one of the most commonly used to analyze the health situation of a given region, and the factors of this mortality target are considered as a concern among the community.

However, the limitations of this study must be recognized. The period used was between

\section{REFERENCES}

1. Figueiredo PP, Lunardi Filho WD, Lunardi VL, Pimpão FD. Infant mortality and prenatal care: contributions of the clinic in the light of Canguilhem and Foucault. Rev. Latino-Am. Enfermagem. 2012; 20(1): p.201-210.

2. Hill K, You D, Inoue M, Oestergaard MZ. Child mortality estimation: accelerated progress in reducing global child mortality, 1990-2010. PLoS Med. 2012; 9(8): p.1001-1303.

3. Liu L, Johnson HL, Cousens S, Perin J, Scott S, Lawn JE, et al. Global, regional, and national causes of child mortality: an updated systematic analysis for 2010 with time trends since 2000. The Lancet. 2012; 379(9832): p. 2151-2161.

4. Atrash HK. Childhood mortality: still a global priority. Journal of Human Growth and Development. 2013; 23(3): p.257-260.

5. UNICEF. Levels and trends in child mortality report, 2013 - estimates developed by the UN Interagency Group for Child Mortality Estimation. [Internet]. [acesso 8 set 2015].

6. Ceará. Informe epidemiológico - Mortalidade Infantil. Fortaleza: Secretaria de Saúde do Estado do Ceará, Núcleo de vigilância epidemiológica; 2014; p.1-11

7. Barros FC, Victora PCG, Barros AJ, Santos IS, Albernaz E, Matijasevich A, et al. The challenge of reducing neonatal mortality in middle-income countries: findings from three Brazilian birth cohorts in 1982, 1993, and 2004. The Lancet. 2005; 365(9462): p.847-854.

8. Mombelli MA, Sass A, Molena CAF, Téston EF, Marcon SS. Risk factors for child mortality in towns of Paraná State (South Brazil), from 1997 to 2008. Rev Paul Pediatr. 2012; 30(2): p.187-194

9. Queiroz IS. The Metropolitan Region of Cariri. Rev Mercator. 2014;13 (3): p.93-104.

10. Frias PG, Szwarcwald CL, Lira PIC. Estimating infant mortality in a decentralized National Health System. Rev. Bras. Saúde Matern. Infant. $2011 ; 11(4)$ : p.463-470.

11. Silva CMCD, Gomes KRO, Rocha OAMS, Almeida IMLM, Neto JMM. Validity and reliability of data and avoidability of the underlying cause of neo-
January 2009 to December 2013 (60 months), and birth alive declarations were used as well, whose fill is not homogeny. The highlight of this study is that infant mortality is related to vaginal birth.

\section{CONCLUSION}

Infant mortality-related variables in the metropolitan region of Brazil were associated mostly with deaths occurring in boys, drab, with birth weight below normal, whose mothers were young, with good education who had only one gestation and born of vaginal birth.

natal deaths in the intensive care unit of the North-Northeast Perinatal Care Network. Cad Saúde Pública. 2013; 29(3): p.547-556.

12. Ribeiro AM, Guimarães MJ, Lima MdC, Sarinho SW, Coutinho SB. Risk factors for neonatal mortality among children with low birth weight. Rev Saúde Pública. 2009; 43(2): p.246-255.

13. Soares ES, Menezes GMS. Factors Associated with Neonatal Mortality: Situation Analysis at the Local Level. Epidemiol Serv Saúde. 2010; 19(1): p.51-60.

14. Jobim R, Aerts D. Avoidable infant mortality and associated factors in Porto Alegre, Southern Brazil, 2000-2003. Cad Saúde Pública. 2008; 24(1): p.178-187.

15. Moreira KFA, Oliveira TS, Gonçalves TA, Moura CO, Maluf SN, Tavares RSA, Tavares CM. Child mortality in the last five-year periods in the city of Porto Velho, RO, Brazil. Journal of Human Growth and Development. 2014; 24(1): p.86-92.

16. Maia RRP, Souza JMP. Factors associated with the low birth weight in municipality in northern Brazil. Journal of Human Growth and Development. 2010; 20(3): p.735-744.

17. Borba GG, Neves ET, Arrué AM, Silveira A, Zamberlan KC. Fatores associados à morbimortalidade neonatal: um estudo de revisão. Saúde (Santa Maria). 2014; 40(1): p.9-14.

18. He X, Akil L, Aker WG, Hwang HM, Ahmad HA. Trends in Infant Mortality in United States: A Brief Study of the Southeastern States from 2005-2009. Int J Environ Res Public Health. 2015; 12(5): p.4908-4920.

19. Atrash HK. Parents' death and its implications for child survival. Journal of Human Growth and Development. 2011; 21(3): p.759-770.

20. Hernandez AR, Silva CH, Agranonik M, Quadros FM, Goldani MZ. Analysis of infant mortality trends and risk factors in Porto Alegre, Rio Grande do Sul State, Brazil, 1996-2008. Cad Saúde Pública. 2011; 27(11): p.2188-2196.

21. Barbosa DRM, Almeida MG. Clinical and epidemiological characteristics and spatial distribution of infant mortality in northeastern brazil, in the period 2008-2011. Revista Eletrônica Gestão \& Saúde. 2014; 5(2): p.569-581. 
22. Silva ZP, Almeida MF, Ortiz LP, Alencar GP, Alencar AP, Schoeps D, Minuci EG, Novaes GMD. Maternal and neonatal characteristics and early neonatal mortality in Greater Metropolitan São Paulo, Brazil. Cad Saúde Pública. 2009; 25(9): p.1981-1989

23. Silva AL, Mathias TAF. Independent risk factors associated with infant deaths. Acta Paul Enferm.
$2014 ; 27(1):$ p.48-56.

24. Suzuki CM, Ceccon MEJ, Falcão MC, Vaz FAC. Comparative analysis of prematurity and low birth weight between newborns of adolescent and adult mothers. Revista Brasileira de Crescimento e Desenvolvimento Humano. 2007; 17(3): p.95-103.

\section{Resumo}

Introdução: A identificação de fatores relacionados aos óbitos infantis pode auxiliar no planejamento de ações de saúde pública para a reestruturação e melhoria da assistência materno-infantil, visando à redução da mortalidade infantil. Objetivo: Analisar os fatores associados à mortalidade infantil na Região Metropolitana do Cariri, Ceará, Brasil. Método: Trata-se de estudo transversal. Foram considerados todos os óbitos ocorridos em crianças menores de um ano de idade dos municípios da Região Metropolitana do Cariri contidas no sistema de informação sobre mortalidade e sistema de informação sobre nascidos vivos, entre janeiro de 2009 a dezembro de 2013. Variáveis do recémnascido (sexo, raça/cor, peso ao nascer, idade); variáveis maternas (idade e escolaridade materna, e tipo de gestação); variáveis de assistência (tipo de parto) foram extraídas do Departamento de Informática do Sistema Único de Saúde e apresentados em gráfico e tabelas na forma de frequência absoluta e percentual. Resultados: No quinquênio, registrou-se 816 óbitos infantis de 48321 nascidos vivos associados aos seguintes fatores: $453(55,5 \%)$ sexo masculino, $471(57,7 \%)$ cor parda e 514 $(63 \%)$ baixo peso ao nascer, $458(56,1 \%)$ de 20 a 34 anos de idade, $353(43,2 \%)$ escolaridade maior ou igual a 8 anos, $657(80,5 \%)$ gestação única e $414(50,7 \%)$ parto vaginal. Conclusão: As variáveis relacionadas à mortalidade infantil na região metropolitana do cariri foram associadas em sua maioria com óbitos ocorridos em meninos, de cor parda, com peso ao nascer abaixo do normal, cujas mães eram jovens, com boa escolaridade e que tiveram gestação única, nascidos de parto vaginal.

Palavras-chave: fatores de risco, recém-nascido de baixo peso, idade materna, assistência perinatal. 